Egyptian Journal of Aquatic Biology \& Fisheries

Zoology Department, Faculty of Science,

Ain Shams University, Cairo, Egypt.

ISSN $1110-6131$

Vol. 22(5): 231- 240 (2018)

www.ejabf.journals.ekb.eg

\title{
Influence of saponin fraction from Albizia anthelmintica on Biomphalaria alexandrina snail; the intermediate host of Schistosoma mansoni in Egypt
}

\author{
Dina M. Bahgat ${ }^{1}$, Hanan S. Mossalem ${ }^{2 *}$, Eman Al-Sayed ${ }^{1}$, Omayma A. Eldahshan ${ }^{1}$, \\ Abdel Nasser B. Singab ${ }^{1}$ and Hanaa M. Abu El Einin ${ }^{2}$ \\ 1- Department of Pharmacognosy, Faculty of Pharmacy, Ain-Shams University, Cairo, Egypt. \\ 2- Department of Environ. Research and Malacology, Theodor Bilharz Research Institute, Egypt. \\ * Corresponding Author: hanan.mossalem@yahoo.com
}

\section{ARTICLE INFO \\ Article History: \\ Received: Sept. 16, 2018 \\ Accepted: Oct. 29, 2018 \\ Available online: Nov. 2018}

Keywords:

Albizia anthelmintica

B.alexandrina

Schistosoma mansoni

Saponin

Schistosomiasis

\section{ABSTRACT}

Saponin fraction from $A$. anthelmintica has a promising molluscicidal effect against snails for $\mathrm{LC}_{50}$ of $17.6 \mathrm{ppm}$ as well as a strong biocidal activity against the larval stages of $S$. mansoni (miracidia and cercariae). A high significant decrease $(p<0.001)$ was recorded in infection rate and survival rate during continuous exposure of the plant; being $50 \pm 10$ and $44.66 \pm 5.05$ respectively compared with $81 \pm 10.1$ in control groups respectively. Light microscopic investigation showed that the tested plant is responsible for the increase of snail's amoebocytes that is consider a main component of the internal defense system of the $B$. alexandrina snails. Electron microscopic examination showed remarkable apoptotic effects, nuclear chromatin condensation, vacuolated cytoplasm and deterioration in the internal organs as endoplasmic reticulum. It is concluded that exposure of $B$. alexandrina snails to saponin fraction from $A$. anthelmintica may be used as a promising molluscicidal and biocidal against the $S$. mansoni parasite.

\section{INTRODUCTION}

Schistosomiasis is one of the most important neglected tropical diseases. Despite effective chemotherapeutic treatments, this disease continues to afflict hundreds of millions of people, at least 218 million people required preventive treatment for schistosomiasis and More than 66.5 million people were reported to have been treated for schistosomiasis in 2015 (WHO, 2017). Understanding the natural intermediate snail hosts of schistosome parasites is vital to the suppression of this disease. Fresh water snails Biomphalaria alexandrina represents the intermediate host for Schistosoma mansoni. Control of S. mansoni by moluscicides plant origin was used for this purpose to reduce of schistosomiasis transmissioin in infected areas. Molluscicides from plant origin aregaining increased attention as they seem to be less expensive, more available, have low toxicity to non target organisms and have no side effect for other aquatic organisms and safe for all environment components (Ibrahim et al., 2004). There is a great interest in the use of molluscicides from plant origin by local community in self-supporting system of schistosomiasis control programe.

Such molluscicides are cheap, safe, available, rapidly biodegradable and probably easily applicable with simple techniques appropriate to developing countries. 
Plant molluscicides have been regarded as possible alternatives to the costly and environmentally hazardous molluscicides currently available (Oliveira-Filho et al., 2010). More than 1000 plant species have been screened for molluscicidal activity, and some plants acts a great potential value as molluscicides, such as Cryptostegia grandiflora (Elsayed, et al., 2011), Yucca desmetiana (Diab et al, 2012), Nerium indicum (Dai et al, 2011), Eucalyptus globules (Al-Sayed et al, 2014), Saraca asoca (Dos Santos et al, 2014), Pueraria peduncularis (Yang et al,. 2017) and Moringa oleifera (Ibrahim and Abdalla, 2017). A few major effective active compounds have been identified, such as saponins and alkaloids.

Saponins are steroid or triterpenoid glycosides, common in a large number of plants and plant products that are important in human and animal nutrition. These structurally diverse compounds have been observed to kill protozoans and mollusks. The molluscicidal activity of saponins were first observed by Lemma (1965) who noticed the toxic effects of extracts of unripe berries of Phytolacca dodecandra on river snails in Ethiopia. Efforts were then mounted to utilize this property of saponins to control diseases such as schistosomiasis. Saponins extracted from many other sources were also seen to have similar molluscicidal properties, for example purified Sesbania sesban saponins at 3-25 mg/kg (Dorsaz et al. 1988) and purified saponin mixtures from Maesa lanceolata at above 5 parts per million (Sindambiwe et al. 1998) have been found to be active against Biomphalaria glabrata. The molluscicidal activity of the saponins may be due to their characteristic detergent effect on the soft body membranes of the molluscs.

The genus Albizia (Fabaceae) comprises about 150 species that are widely distributed in Africa and South America. Albizia species were reported as rich in phenolic compounds, saponins, and triterpenoidal saponins. Saponin glycosides with diverse pharmacological activities were isolated from different Albizia species (Zhang, et al, 2011, Singab et al 2015). Still now there are no studies on the activity of Albizia anthelmintica extracts against snails.

The aim of the present study was to evaluate the effect of saponin isolated from A.anthelimintica as a plant origin on susceptibility of B. alexandrina snails to infection with S. mansoni and on the count and morphology changes of hemocytes and as a possible safe method of schistosomiasis control.

\section{MATERIALS AND METHODS}

\section{Snails}

Biomphalaria alexandrina snails were collected from different water courses at Giza Governorate, Egypt, and transferred in plastic bags to the laboratory. Snails were reared in de-chlorinated water $\left(25^{\circ} \mathrm{C} \pm 1\right)$ (Liang et al., 1987) at Medical Malacology Laboratory, Theodor Bilharz Research Institute (TBRI), Imbaba, Giza, Egypt. Healthy snails free from trematode infections were used in the experimental testes.

\section{Plant Material}

The leaves of $A$. anthelmintica BRONGN were collected in January 2013 from the Zoo, Giza, Egypt. They were kindly authenticated by Mrs. Therease Labib, the taxonomy specialist in El-Orman Botanical Garden, Giza, Egypt. A voucher specimen (PHG-P-AA-2013) was deposited with the Herbarium of the Faculty of Pharmacy, Ain Shams University, Cairo, Egypt.

\section{Molluscicidal activity}


A stock solution of $20 \mathrm{ppm}$ was prepared from saponin fraction from Albizia anthelmintica extract on the basis of w/v using de-chlorinated water ( $\mathrm{pH} 7.0$ to 7.5). A series of concentrations was prepared on the basis of volume/volume (WHO 1965). Three replicates were used, each of ten snails ( 5 to $7 \mathrm{~mm} / \mathrm{L}$, for each concentration $\left(\mathrm{LC}_{10}, \mathrm{LC}_{25}, \mathrm{LC}_{50}, \mathrm{LC}_{0}\right)$. Exposure and recovery periods were $24 \mathrm{~h}$ each; at $25 \pm$ $1^{\circ} \mathrm{C}$. For each test, 3 replicates of control snails were maintained under the same experimental conditions in de-chlorinated water. The effectiveness of saponin fraction from Albizia anthelmintica has been expressed as $\mathrm{LC}_{50}$ and $\mathrm{LC}_{90}$ (Litchfield and Wilcoxon, 1949). The used concentrations were calculated through a computer program (IPM SPSS Statistics program, version 20 for Windows), employing the probit analysis (Finney, 1971).

\section{Exposure of snails to saponin and to shistosome mansoni}

Four groups of $B$, alexandrina snails $(5-7 \mathrm{~mm})$ were exposed for $S$. mansoni mircidia of (8 miacidia /snail), Ffirst group represent control group, other groups were exposed to $20 \mathrm{ppm}$ of saponin of A. antheletica at the same time of miracidial exposure these groups represent exposed group, three replicates (each replicate of 10 snails/L in glass container) were prepared for each group. After that, snails were transferred to clean de-chlorinated water $\left(25 \pm 1{ }^{\circ} \mathrm{C}\right)$ and daily fed with oven dried lettuce leaves throughout the pre-patent and patent periods (Massoud et al., 1973). A control group of three replicates, each 10 snails/L was exposed to miracidia concurrently with the experimental snails and treated similarly till cercarial emergence. Dead snails were removed daily and surviving snails were individually examined once weekly for cercarial shedding 24 days post-miracidial exposure. The number of snails survived at the first shedding and the number of infected snails were calculated. The survival and infection rates were compared with that of control using chi -test of excel

\section{Miracidicidal and cercaricidal activity}

Ten milliliters of water containing approximately 100 freshly hatched miracidia, freshly shed cercariae was mixed with $10 \mathrm{~mL}$ of $40 \mathrm{ppm}$ extract obtain a concentration of $20 \mathrm{ppm}$ (Mostafa \& Gawish 2009). Approximately equal numbers of miracidia, cercariae in $20 \mathrm{~mL}$ of dechlorinated water were used as the control. Three replicates were used for each test. Microscopic observation of the movement and mortality of the miracidia and cercariae were performed every $15 \mathrm{~min}$. The organisms were considered dead when their motion ceased completely. The dead organisms were then counted.

\section{Hemocytes investigation: \\ Light microscopy:}

Hemolymph samples were collected from each group of exposed snails by removing a small portion of the shell and inserting a capillary tube into the heart. The hemolymph pooled from 10 snails and collected in a $1.5 \mathrm{ml}$ Eppendorf tube according to Michelson (1966) and kept in an icebox for microscopic examinations. Blood films were stained with Fleishmann, Giemsa stains and examined according to Mossalem et al. (2013). The number of each blood cell type was calculated, represented as a percentage per 100 of cells and photographed by Primo Star ILed, AxioCam ERcS5 digital Camera.

\section{Electron microscopy:}

The collected hemolymph were centrifuged and the sedimented cells were fixed in $4 \%$ glutaraldhyde with sodium cacodylate, Two hours later , the cells were postfixed in $2 \%$ osmium tetraoxide, dehydrated with ascending concentration of alcohol and embedded in epoxy resin according to the technique of (Grimaud et al., 
1980). Semi-thin and ultra- thin sections were cut with a Leika ultra microtome. Ultra- thin sections were contrasted with uranyl acetate and lead citrate stains then examined by Phillips EM 208 Electron Microscope.

\section{Statistical analysis:}

The data are presented as mean \pm standard deviation). The means of the different groups were compared globally using the student's t- test (Sokal and Rohlf, 1981).

\section{RESULTS DISCUSSION}

The Molluscicidal activity of saponin fraction from $A$. anthelmintica against $B$. alexandrina snails is more affected for snails with lethal concentration $\mathrm{LC}_{50}=17.6$ ppm Table (1).

Table 1: Molluscicidal activity of saponin fraction from A. anthelmintica on B. alexandrina snail

\begin{tabular}{|c|c|c|c|c|}
\hline Concentration & $\mathrm{LC}_{10}(\mathrm{ppm})$ & $\mathrm{LC}_{25}(\mathrm{ppm})$ & $\mathrm{LC}_{50}(\mathrm{ppm})$ & $\mathrm{LC}_{90}(\mathrm{ppm})$ \\
\hline Saponin of A.anthelmintica & 9.9 & 13.6 & 17.6 & 25.3 \\
\hline
\end{tabular}

A high significant $(\mathrm{p}<0.001)$ decrease in infection rate and survival rate during continuous exposure of plant for one month showed (50\%) than control ( $81 \%$ ) for infection rate and $44.66 \%$ for survival rate when compared with control $96 \%$ Table (2).

Table 2: Effect of a saponin fraction from A. anthelmintica continuous exposed for one month on $B$. alexandrina snail's infection rate and survival rate.

\begin{tabular}{|c|c|c|}
\hline Sample type & Infection rate & Survival rate \\
\hline & $\mathrm{M} \pm \mathrm{SD}$ & $\mathrm{M} \pm \mathrm{SD}$ \\
\hline Control & $81 \pm 10.1$ & $96 \pm 1.0$ \\
\hline Infected & $50 \pm 10^{* * *}$ & $44.66 \pm 5.05^{* * *}$ \\
\hline
\end{tabular}

Saponin fraction from A. anthelmintica had strong miracidicidal activity (100\% inhibition) through $1 / 2 \mathrm{~h}$ exposure and highest cercaricidal activity $70 \& 100 \%$ after $1 / 2$ $\mathrm{h}$ minutes \& $1 \mathrm{~h}$ exposure, respectivelyTable(3).

Table 3: Effect of a saponin fraction from A. anthelmintica on S. mansoni miracidia and cercariae.

\begin{tabular}{|l|lc|lc|}
\hline Plant & \multicolumn{2}{|l|}{ Miracidicidal activity $\%$} & \multicolumn{2}{l|}{ Cercaricidal activity\% } \\
\hline time & $1 / 2 \mathrm{~h}$ & $1 \mathrm{~h}$ & $1 / 2 \mathrm{~h}$ & $1 \mathrm{~h}$ \\
\hline Control & 0 & 0 & 0 & 0 \\
\hline A. anthelmintica & 100 & 0 & 70 & 100 \\
\hline
\end{tabular}

Examination of $B$. alexandrina hemolymph by light and electron microscopy revealed three types of different cells classified according to their shape and granular contents. These cells are: - Granulocytes, Amoebocytes and Hyalinocyte as shown in Fig (1). Morphological alter of hemocytes category Amoebocytes, Granulocytes and Hyalinocytes which are key immune elements in B. alexandrina snails. Volume size, shape and their number showed very high significant rework as decreased at two types as follows $23.3 \%, 6.6 \%$ Granulocytes, Hyalinocytes in compared with control $50.3 \%, 23 \%$ plus high increased in Amoebocytes $70 \%$ in link to control 25\% table(4). Histological transform as remarkable apoptotic changes represented by nuclear chromatin condensation, eccentric nucleus and fragmentation, vacuolated cytoplasm, deterioration in the internal organs as endoplasmic reticulum as shown in Fig ( $1 \& 2)$ 
Table 4: Percentage of hemocytes in the hemolymph of $B$. alexandrina snails exposed to saponin fraction from $A$. anthelmintica for one-month infection with $S$. mansoni.

\begin{tabular}{|l|c|c|c|}
\hline Hemocyte type & Amoebocyte (\%) & Granulocyte (\%) & Hyalinocyte(\%) \\
\cline { 1 - 3 } Sample type & & & 23 \\
\hline Control & 25 & 50 & $6.6^{* * *}$ \\
\hline
\end{tabular}
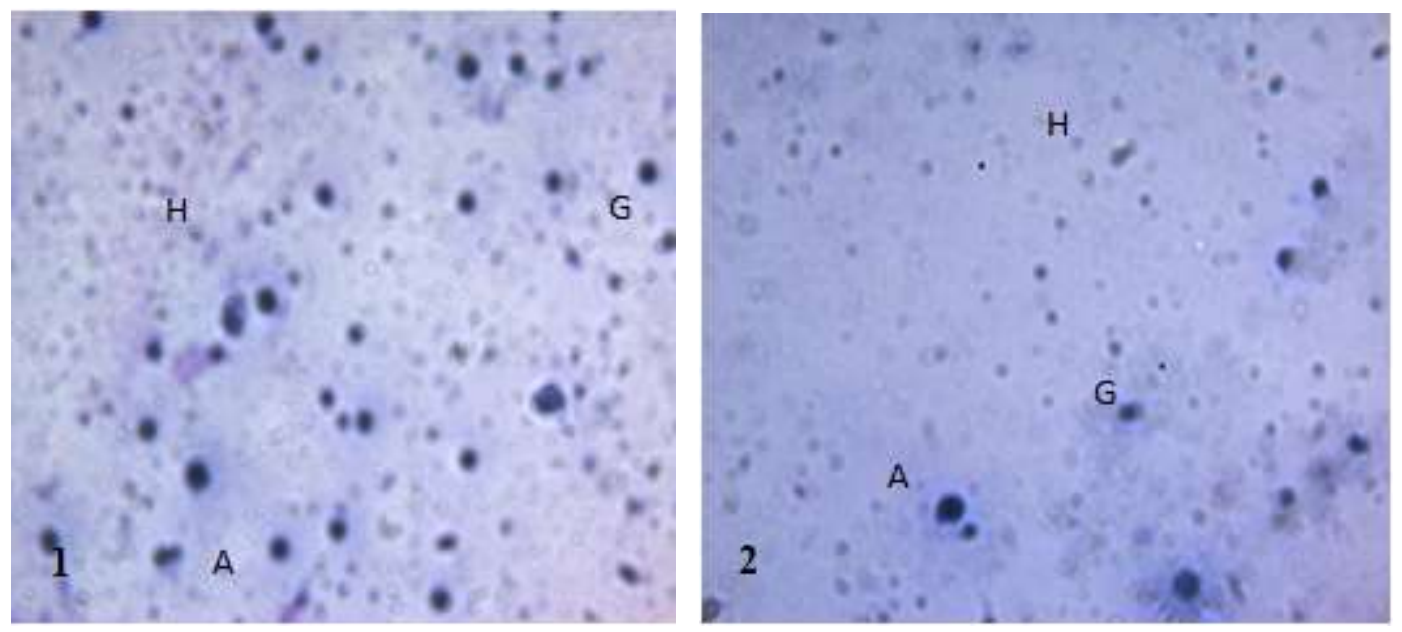

Fig. 1: light microscope digital cameara showing Three types of hemocytes of Biomphalaria alexandrina hemolymph A Amoebocyte, $\mathrm{H}$ Hyalinocyte, $\mathrm{G}$ Granulocyte 1: Control wih large number of haemocytes 2: after treated with saponin fraction from A. anthelmintica for one month infection with $S$. mansoni with decrease in hemocyte number .
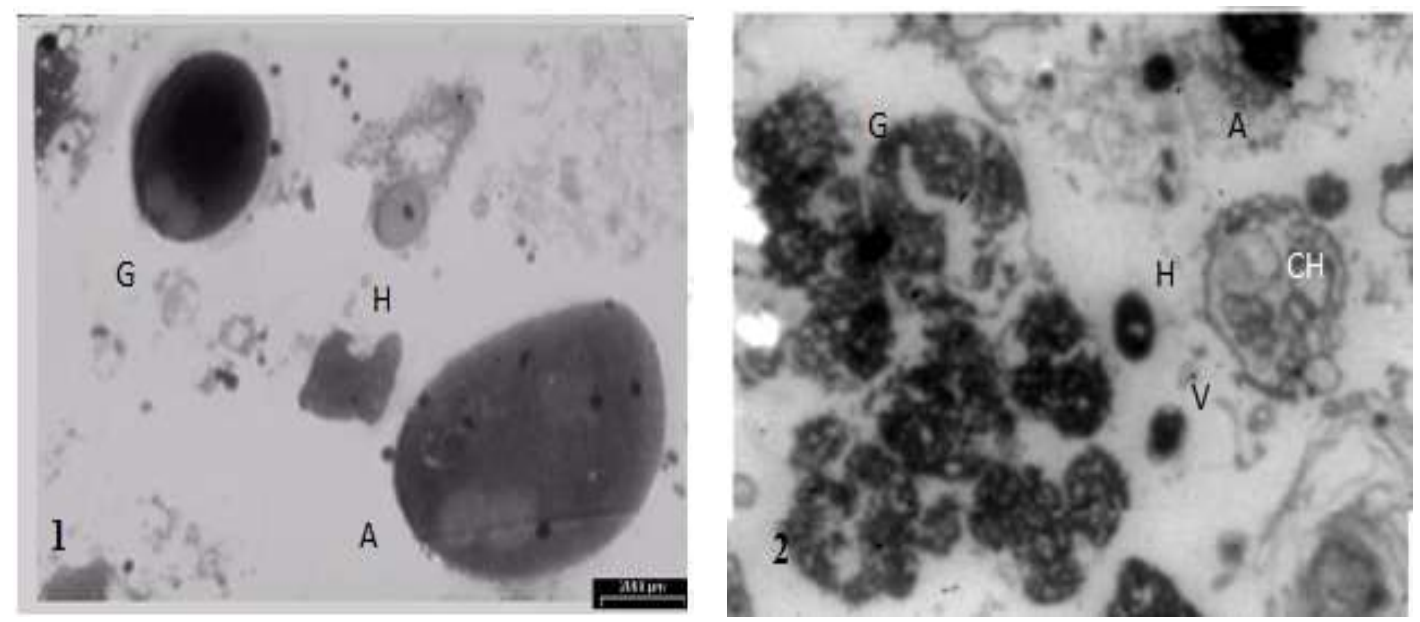

Fig. 2: Ultrastructure of hemocytes 1- Normal hemocytes of B. alexandrina illustrate A amoebocyte, G granulocyte and $\mathrm{H}$ hyalinocyte 2 - hemocytes of $B$. alexandrina after exposed to saponin fraction from A. anthelmintica for one month infection with $\mathrm{S}$. mansoni for one month point up $\mathrm{CH}$ nuclear chromatin condensation, eccentric nucleus and fragmentation, VC vacuolated cytoplasm, deterioration in the internal organs as endoplasmic reticulum.

\section{DISCUSSION}

The Albizia members in Africa are used in folk medicine for the treatment of rheumatism, cough, diarrhea and injuries (Watt, and Breyer 1962). Phytochemical studies carried out on Albizia species led to the isolation of several triterpene glycosides, flavonoids, alkaloids and miscellaneous compounds. Albizia anthelmintica is cultivated widely in Africa and Asia. East Africans widely use $A$. 
anthelmintica to control helminth parasites in human and animal medicine in Sudan (koko, 2000) and Ethiopia (Desta, 1995). In the present study, plant was tested for molluscicidal effect, the extract of plant found to be more toxic to schistosomiasis vector snail $B$. alexandrina. The killing effect of the plant due to the presence of the active component saponins. (Tadros et al., 2008) found that the steroidal saponincontaining fraction from methanolic extract of the plant Dracaena fragrans had a considerable molluscicidal activity against $B$. alexandrina and Bulinus. truncatus snails.

The results of the present study indicate that maintenance of snails in $\mathrm{LC}_{50}$ concentration of $A$. anthelmintica for one month results a significant reduction of the infection rate and survival rate for treated snails versus control ones. This may be explained by the deterioration of physiological parameters of snails making them unsuitable for the parasite development. These results agree with other authors (Al Shakaway et al, 1996; Gawish and El Bardicy, 2004, Gawish, 2008) who reported the toxic molluscicidal effectiveness of various plants against schistomiasis vector snails and their susceptibility to infection with schistosome miracidia. (El- Ansary et al., 2000) reported that Ambrosia maritima caused a remarkable decrease in cercarial shedding from Biomphalaria treated with the plant powder. Moreover (Massoud et al., 2004) found that no S.mansoni cercariae were produced from B.alexandrina snails treated with $\mathrm{LC}_{20}$ of oleo resin from the plant Commiphora molmol (Myrrh), whereas, those exposed to $\mathrm{LC}_{10}$ showed a considerable reduction in the infection rate and cercarial production.

Most of the plants screened against schistosomiasis cercariae and miracidia were generally effective at levels less than that of their molluscicidal ones. Regarding the miracidicidal and cercaricidal activities, the present study showed that $100 \%$ inhibition for miracidia and cercarial after $1 / 2$ hour and one-hour exposure to the concentration of $\mathrm{LC}_{50}$ of $A$. anthelmintica respectively. Methanol extracts of plants Callistemon citrinus, Punica granatum and Pumpkin killed $100 \%$ of the treated S. mansoni miracidia and cercariae after 30 minutes of exposure to $\mathrm{LC}_{90}$ (Ammar et al, 2016). However dry powder of Calendula micrantha 100 ppm were killed miracidia and cercariae within 2 and $24 \mathrm{~h}$ of exposure, respectively (El-Emam, 1986).

The Biomphalaria immune response is mounted both by cellular effectors (i.e. via the hemocytes (Nacif-Pimenta et al, 2012), and humoral factors (Mitta et al, 2012), acting independently or together to fight invading microbes or parasites (Coustau et al, 2015) Many snail humoral factors have been carefully characterized in the Biomphalaria genus to identify the resistance mechanisms to schistosome infection. The first line of defense is mediated by circulating phagocytic cells known as hemocytes (also known as amoebocytes) found in the hemolymph of the snail. These cells have an important role in phagocytosis and encapsulation reactions. The use of molluscicides in the control of fresh water snails is now approaching a highly developed state and plants having molluscicidal properties were found to suppress the total number of snail's hemocytes. In the present study three main types of hemocytes were detected in the hemolymph of untreated $B$. alexandrina by light $\&$ electron microscopy. The main cell was granulocytes $(50 \%)$ followed by amoebocytes (25\%) and hyalinocytes $(23 \%)$. Granulocytes and hyalinocytes of snails treated with the tested plant decreased to $23 \%$ and $6.6 \%$ respectively. This reduction may be due to the fact that snails become unhealthy and change in physiological parameter as the result of continuous exposure to the tested plant. The reduction in hemocytes after treatment with plant could also be a result from a direct action of the plant on these cells. The increase in the number of amoebocytes $70 \%$ is of specific importance to 
snails since it represents the first line of defense. The immune response of these blood cells is mediated by infiltration around the parasite, encapsulation, and phagocytosis. This result agrees with the findings of (Martin et al, 2006, Souza \& Andrade, 2006 and Mossalem et al. 2014), On the other hand, the number of circulating hemocytes was highly variable in Biomphalaria and mainly dependent on parameters such as the method and site of hemolymph extraction besides the physiological conditions of the snail (Sminia, 1981).

\section{CONCLUSION}

Exposed of tested snails to $\mathrm{LC}_{50}$ of saponin fraction from of $A$. anthelmintica showed strong activity against intermediate host snail and larval stages of $S$. mansoni. It is evident thatsaponin fraction from of $A$. anthelmintica, May be used for snail control which is one of the efficient methods to control this parasite. and evaluated in the field to determine its potential use as natural products.

\section{REFERENCES}

Ammar, A., El hefnawy, N., Mahmoud, S., sabry, H., Gawish, F., Aly I., and Refahy, L. (2016). Evaluation of Callistemon citrinus, Punica granatum and Pumpkin against molluscicidal and free larval stages of Schistosoma mansoni. IJBPAS, 2863-2884.

Al-Sayed, E., Hamid, H.A., and Abu El Einin, H.M. (2014). Molluscicidal and antischistosomal activities of methanol extracts and isolated compounds from Eucalyptus globulus and Melaleuca styphelioides. Pharm Biol., 52:698-705.

Al-Sharkawy, I. M., Mansour, M. A., and Tolba, G. A. (1996). Preliminary laboratory investigation of molluscicidal activities of some widely distributed in the Nile Delta. J. Egypt. Germ. Soc. Zol., 20(A): 235.

Chitsulo, L., Loverde, R., Engels, D., Barakat, R., Colley, D., Cioli, D., Engels, D., Feldmeier, H.M., Loverde, P., Olds, J., Ourna, G.R., Rabello, A., Savioli, L., Traore, M.B., and Ennerwald, V. (2004). Schistosomiasis. Nat. Rev. Microbiol., 2:12-13.

Coustau, C., Gourbal, B., Duval, D, Yoshino ,T.P, Adema, C.M., and Mitta G. (2015). Advances in gastropod immunity from the study of the interaction between the snail Biomphalaria glabrata and its parasites: A review of research progress over the last decade. Fish Shellfish Immunol, 46(1):5-16.

Dai, L., Wang, W., Dong, X.., Hu, R., and Nan, X. (2011). Molluscicidal activity of cardiac glycosides from Nerium indicum against Pomacea canaliculata and its implications for the mechanisms of toxicity. Environ Toxicol Pharmacol, 32:226-232 (2011).

Desta, B. (1995). Ethiopian traditional herbal drugs. Part I studies on the toxicity and therapeutic activity of local taenicidal medications. J. Ethnopharmacol., 45: 27-33.

Diab, Y., Ioannou, E., Emam ,A., Vagias, C., and Roussis, V., and Desmettianosides, A. B. (2012). bisdesmosidic furostanol saponins with molluscicidal activity from Yucca desmettiana. Steroids, 77:686-690.

Dorsaz, A. C., Hostettmann, M. and Hostettmann, K. (1988). Molluscicidal saponins from Sesbania sesban. Planta Medica, 54: 225-227.

Dos Santos, A. F., Fonseca, S. A., César, F. A., De Azevedo Albuquerque, M. C., Santana, J.V., and Santana , A. E. (2014). A penta-substituted pyridine 
alkaloid from the rhizome of Jatropha elliptica (Pohl) Muell. Arg. is active against Schistosoma mansoni and Biomphalaria glabrata. Parasitol Res., 113:1077-1084.

El-Ansary, A., El-Bardicy, S., Soliman, M. S., and Zayed, N. (2000). Sublethal concentration of Ambrosia maritima (Damsissa) affecting compatibility of Biomphalaria alexandrina snails to infection with Schistosoma mansoni through disturbing the glycolytic pathway. J. Egypt. Soc. Parasitol., 30(3): 809.

El-Emam, M.A.; H.A. Shoeb; F.A. Ebid and Refai, L.A. (1986). Snail control by Calendula micrantha officinalis. J. Egypt. Soc. Parasitol., 16 (2): 563-571.

Finney, I. J. (1952). Probit analysis. Cambridge, England: Cambridge University Press

Gawish, F., El-Bardicy, S. (2004). Activity of Solanum nigrum and Ambrosia maritima plants on susceptibility of Biomphalaria glabrata snails and albino mice to Peurto Rican strain of Schistosoma mansoni. J. Egypt. Ger. Soc. Zool., 43(D): 203

Gawish, F., Mossalem, H. S., Abu El-Einin, H. (2008). Bioassay of the plant Callistemon citriun against Bulinus truncatus snails and their infection with Schistosoma haematobium. Egypt J. Schisto. Infect. Endem. Dis., 30: :33-41.

Grimaud, J. A., Druguet, M., Peyrol, S., et al. (1980). Collagen immunotyping in human liver: Light and electron microscope study. The Journal of Histochemistry and Cytochemistry: Official Journal of the Histochemistry Society 28(11): 1145-1156.

Ibrahim, A. M., and Abdalla, A. M. (2017). Impact of Moringa oleifera seed aqueous extract on some biological, biochemical, and histological aspects of Biomphalaria alexandrina snails. Environ Sci Pollut Res Int. doi: 10.1007/s11356-017-0397.

Ibrahim, A. M., El-Emam, M. A., El-Dafrawy, S. M., and Mossalem, H. S. (2004). Impact of certain plant species on Schistosoma mansoni Biomphalaria alexandrina system. Proceeding $3^{\text {rd }}$ Inter. Con. Sci.e 3:390-413.

Koko, W. S., Galal, M..,and Khalid, H. S. (2000) . Fasciolicidal efficacy of Albizia anthelmintica and Balanitesa egyptiaca compared with albendazole. J. Ethnopharmacol., 71(1): 247-252.

Lemma, A. (1965). A preliminary report on the molluscicidal property of endod (Phytolacca dodecandra ). Ethiopian Medical Journal, 3:187.

Liang, Y. S.; Bruce, J. I. and Body, D. A. (1987). Laboratory cultivation of schistosome vector snails and maintenance of schistosome life cycle. Proc. 1st Sino-Amer. Symp, 1: 34- 48.

Litchfield, J.T., and WiLcoxon, F. (1949). A simplified method of evaluating dose effect experiments. J. Pharmacol. Exp. Therap., 96:99-113.

Martins-Souza, R. L., Pereira, C. A., Martins Filho, O. A., Coelho, P. M., Corrêa, A. J. and Negrão-Corrêa, D. (2006) Differential lectin labeling of circulating hemocytes from Biomphalaria glabrata and Biomphalaria tenagophila resistant or susceptible to Schistosoma mansoni infection. Mem Inst Oswaldo Cruz., 101 Suppl 1: 185.

Massoud, A. M. A., Metwally, D. M., Khalifa, E. K., and Habib, F. S. M. (2004). Compatibility of Biomphalaria alexandrina snails to infection with Schistosoma mansoni after exposure to sublethal concentrations of Myrrh. Journal of the Egyptian Society of Parasitology, 34(3): 995-10.

Michelson, E. H. (1966). Specificity of hemolymph antigens in taxonomic discrimination of medically important snails. J Parasitol, 52(3):466-72.08. 
Mitta, G., Adema, C. M., Gourbal , B., Loker, E. S. and Theron, A. (2012). Compatibility polymorphism in snail/schistosome interactions: From field to theory to molecular mechanisms. Dev Comp Immunol., 37(1):1-8.

Mossalem, H. S., Abdel-Hamid, H. and El-Shinnawy, A. N. (2013). "Impact of artemether on some histological and histochemical parameters in Biomphalaria alexandrina," African Journal of Pharmacy and Pharmacology, 7: 2220-2230.

Mossalem, H. S., and Labib, G. A. (2014). Evaluation of the pesticide Emamectin and methanol extract of Wheat Bran against Biomphalaria alexandrina snails, their hemocytes and their infection with Schistosoma mansoni. Journal of Agriculture and Food Sciences Research., 1(1): 5-10.

Mostafa, S. S. M., and Gawish, F. A. (2009). Towards to control Biomphalaria alexandrina snails and the free living larval stages of Schistosoma Mansoni using the microalga Spirulina platensis. Aust J Basic Appl Sci., 3: 4112-4119.

Nacif-Pimenta, R., Alves de Mattos, A. C., da Silva Orfanó, A., Barbosa, L., Pimenta, P. F. P. and Coelho, P. M. Z. (2012). Schistosoma mansoni in susceptible and resistant snail strains Biomphalaria tenagophila: in vivo tissue response and in vitro hemocyte interactions. PLoS One., 09; 7(9):e45637.

Oliveira-Filho, E. C., Geraldino, B. R., Coelho, D. R., De-Carvalho, R. R. and Paumgartten, F. J. (2010). Comparative toxicity of Euphorbia milii latex and synthetic molluscicides to Biomphalaria glabrata embryos. Chemosphere, 81 (2): 218-27.

Sindambiwe, J. B., Calomme, M., Geerts, S., Pieters, L., Vlietinck, A. J. and Vanden Berghe, D. A. (1998). Evaluation of biological activities of triterpenoid saponins from Maesa lanceolata. J. Natural Products 61: 585-590.

Singab A, Bahgat D., E. Al-Sayed E., Eldahshan, D. (2015). Sponins from Genus Albizhia: phytochemical and biological Review .Med. Aromat. Plants, 1-7

Sminia, T. (1981). Structure and function of blood cells of gastropods. In Invertebrate Blood Cell, Acad Press, New York, p 191.

Sokal, R. R., Rohlf, R. R., Biometry, F.J., Freeman, W. H., and San Francisco, C. o. (1981).

Souza, S. and Andrade, Z. A. (2006). On the origin of the Biomphalaria glabrata hemocyte. Mem. Inst. Oswaldo Cruz. 101 Suppl 1: 213.

Tadros, M. M., Abdel- Khalik, S. M., Melek, F. and Gaber, N. M. (2008). Agave angustifolia: A potential source of control agents against Schistosomiasis mansoni. N. Egypt. J. Med., 39: (2):169.

Watt, J. M. and Breyer-Brandwijk, M. G. (1962). The Medicinal and Poisonous Plants of Southern and Eastern Africa, $2^{\text {nd }}$ Edn. E \& S Livingstone Ltd., London, England,

WHO. (1962). Moluscicide screening and evaluation. Bulletin, 567-581.

WHO. (2017) http://www.who.int/mediacentre/factsheets/fs115/

Yang, C., Zhang, M., Lei, B., Gong, G., Yue, G., Chang, X., Sun, X., Tian, Y., and Chen, H. (2017). Active saponins from root of Pueraria peduncularis (Grah. ex Benth.) Benth. and their molluscicidal effects on Pomacea canaliculata.Pest Manag Sci., 73(6):1143-1147.

Zhang, H., Samadi, A. K., Rao, K. V., Cohen, M. S., and Tim-mermann, B. N. (2011). Cytotoxic oleanane-Type saponins from the leaves of Albizia anthelmintic. J. Nat. Prod., 74: 477-482. 


\section{ARABIC SUMMARY}

Biomphalaria على قأثير مستخلص الصابونين من نبات اللبخ Albizia anthelmintica alexandrina

$$
\begin{aligned}
& \text { دينا بهجت'، حنان شحات مسلم' ، ايمان السيد' ، أميمه الاهشان' ، عبد الناصر سنجاب' }
\end{aligned}
$$

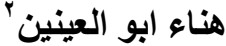

1- ق قسم العقاقير ، كلية الصيدلة ، جامعة عين شمس ، القاهرة ،

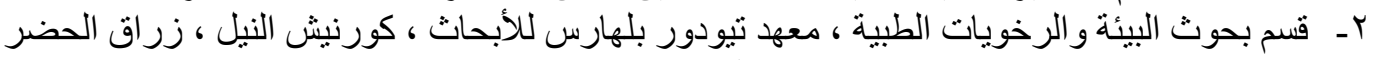

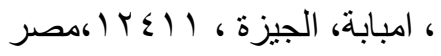

تتم دراسة تأثثر مستخلص الصابونين من نبات اللبخ Albizia anthelmintica على اللأطوار الحرة لطفيل Schistosoma mansoni ، لنسبة العدوى، معدل البقاء على قيد الحياة للقو اقع و على شكل و عدد خلايا الهيموسيت بواسطة الميكروسكوب الضونئى و الالكترونى.

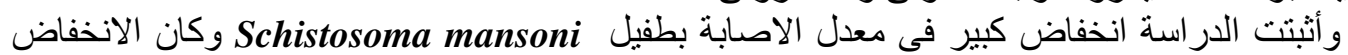

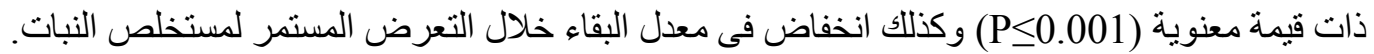

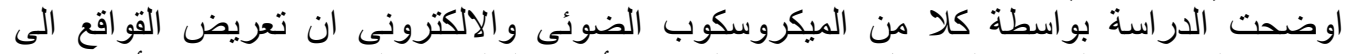

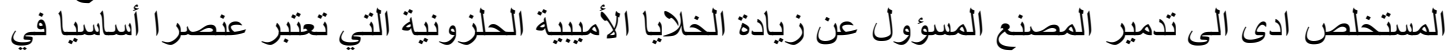

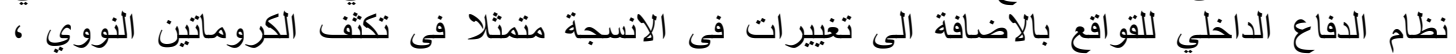

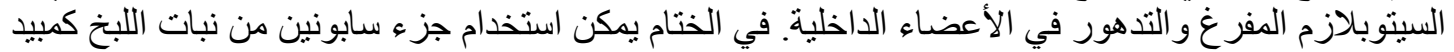
حيوى ضد العائل الوسيط للبلهارسيا المعوية ويرقات الأل الطفيل. 